\title{
A Mysterious Disease - Osteonecrosis of the Jaw
}

\author{
Yi Fang Huang ${ }^{1,2 *}$ and Chung Ta Chang ${ }^{2,3}$ \\ ${ }^{1}$ Department of General Dentistry, Taipei Chang Gung Memorial Hospital, Taiwan \\ ${ }^{2}$ School of Dentistry, College of Oral Medicine, Taipei Medical University, Taiwan \\ ${ }^{3}$ Department of Emergency Medicine, Far Eastern Memorial Hospital, Taiwan
}

Submission: March 27, 2017; Published: April 13, 2017

*Corresponding author: Yi-Fang Huang, Department of General Dentistry, Taipei Chang Gung Memorial Hospital, No.5, Fuxing St., Guishan Township, Taoyuan County 33305, Taiwan, Tel: +886 33281200 ext. 8323; Fax: +886 33278 928; Email: yifang0324@gmail.com

\begin{abstract}
Osteonecrosis of the jaw (ONJ) is a silent and hard diagnostic disease in its early stage. In the past, radiotherapy and bisphosphonates recipients are regarded as major contributing factors for ONJ. As our recent research the dental status play a significant role in ONJ development. ONJ seems a multifactorial outcome although its pathogenic mechanism seems a controversial issue until now. There is no any effective method to avoid ONJ occurrence. Maintaining good oral hygiene could prevent the ONJ. Appropriate oral examination for active or anticipated dental issues prior to bisphosphonates treatment or radiotherapy might be the best way to reduce the ONJ risk.
\end{abstract}

Keywords: Osteonecrosis of the jaw; Dental status; Radiotherapy; Bisphosphonate; Multifactoria

\section{Introduction}

Osteonecrosis of the jaw (ONJ) is defined as a painful lesion with exposed bone in maxilla, mandible, or both which fails to heal within 8 weeks after appropriate treatment [1].

$\mathrm{ONJ}$ is a silent disease because it presents as asymptomatic bone exposure without significant soft tissue infection in its early stage. However, the infected necrotic maxillofacial lesion with ulcerated swollen oral mucosa and chronic sinus tract derived from ONJ usually attack the life quality of patients [2]. The pathogenesis and risk factors of $\mathrm{ONJ}$ is a controversial issue until now and there is no superior and appropriate strategy for this intractable illness. Although the head and neck irradiation and bisphosphonates (BPs) administration are widely accepted as the major risk factors of ONJ [3], our recent study had indicated the dental status significantly impacts on the ONJ development $[4,5]$.

\section{Radiotherapy}

The irradiation exposure on the head and neck region usually induces prominent cellular changes and oral tissue dysfunction [6]. Permanent salivary gland damage could be happened if accumulative doses exceed 30 Gy [7]. Osteoradionecrosis (ORNradiation related necrosis) of the jaw is a common complication in head and neck cancer patients and its incidence is about 1-30\% [8]. Because radiotherapy alters the oral condition, head and neck cancer patients are regarded as a high-risk group to develop ORN.
Based on the consensus proposed by National Institutes of Health, head and neck cancer patients are suggested to receive oral and dental evaluation and treatment before radiotherapy or chemotherapy [9]. Our study proposed in 2017 preliminarily indicated pre-radiotherapy dental prophylaxis is strongly correlated to ORN. It is best to avoid chlorhexidine exposure and dental scaling within two weeks before radiotherapy. That will significantly raise the ORN risk, especially in oral cancer patients. The cautious prescription of chlorhexidine mouth rinse and proper timing of scaling can effectively reduce the incidence of ORN [5].

\section{Bisphosphonate and osteoporosis}

Bisphosphonate-related osteonecrosis of the jaw (BRONJ) is a drug side-effect involving progressive destruction and necrosis in the alveolar bone [10]. The variable incidence of BRONJ ranges from $2.5 \%$ to $27.3 \%$ and most reported cases occurred in cancer patients [11]. Previous study indicated $\mathrm{ONJ}$ is a rare complication if BPs use is less than 5 years [12]. The osteoporosis patients with longer duration and higher dosage of BPs used have significant excess risk for ONJ [4] although the correlation of the BRONJ and the cumulative dosage of BPs is still a controversial issue now. It is essential to discover the best way of BPs administration based on a favorable risk-benefit ratio in the high-risk fracture population. 
Clinicians should be aware the profits of BPs against the risk of BRONJ then define the optimal duration of treatment remains.

\section{Dental Status}

Many Previous study both in human and animal models revealed that periodontitis raises the risk of $\mathrm{ONJ}$ development and the $84 \%$ patients with BRONJ were suffered from periodontitis [13]. Oral hygiene status and the history of dental procedure are highly related to ONJ [14]. Yuh et al. [15] had represented dental extraction plays a significant influence on the ONJ development [15]. This consensus is coincident to the viewpoint we proposed in 2015, there is a close association with annual frequency of dental extraction and ONJ occurrence [4]. Dental status is closely associated with the ONJ occurrence and good oral hygiene maintenance plays the key role in preventing ONJ.

\section{Conclusion}

$\mathrm{ONJ}$ is a multifactorial disease. Osteoporosis, radiotherapy and past dental history play the major effect in some ways and BPs is the synergistic role. Appropriate treatment plan for BPs administration after analyzing every risk factor may reduce the risk of ONJ.

Osteoporosis patients with BPs used had higher risk of ONJ if they received more than twice dental extraction annually. It is essential to examine oral condition for active or anticipated dental issues prior to BPs treatment or radiotherapy. Clinicians should be vigilant for ORN occurrence under chlorhexidine mouth rinse exposure or dental scaling within two weeks prior radiotherapy. Good oral hygiene maintenance to avoid the frequent dental extraction may be the supreme principle to prevent ONJ.

\section{References}

1. Khan AA, Morrison A, Hanley DA, Felsenberg D, McCauley LK, et al. (2015) Diagnosis and management of osteonecrosis of the jaw: a systematic review and international consensus. J Bone Miner Res Jan 30(1): 3-23.

2. Miksad RA, Lai KC, Dodson TB, Woo SB, Treister NS, et al. (2011) Quality of life implications of bisphosphonate-associated osteonecrosis of the jaw. Oncologist 16(1): 121-132.
3. Fellows JL, Rindal DB, Barasch A, Gullion CM, Rush W, et al. (2011) ONJ in two dental practice-based research network regions. J Dent Res 90(4): 433-438.

4. Huang YF, Chang CT, Muo CH, Tsai CH, Shen YF, et al. (2015) Impact of Bisphosphonate- related Osteonecrosis of the Jaw on Osteoporotic Patients after Dental Extraction: A Population-Based Cohort Study. PLOS ONE 10(4): e0120756.

5. Chang CT, Liu SP, Muo CH, Tsai CH, Huang YF (2017) Dental prophylaxis andosteoradionecrosis. Journal of dental research 22034516687282.

6. Mercadante S, Aielli F, Adile C, Ferrera P, Valle A, et al. (2015) Prevalence of oral mucositis, dry mouth, and dysphagia in advanced cancer patients. Support Care Cancer 23(11): 3249-3255.

7. Cassolato SF, Turnbull RS (2003) Xerostomia: clinical aspects and treatment. Gerodontology 20(2): 64-77.

8. Owosho AA, Kadempour A, Yom SK, Randazzo J, Jillian Tsai C, et al. (2015) Radiographic osteoradionecrosis of the jaw with intact mucosa: Proposal of clinical guidelines for early identification of this condition. Oral oncology 51(12): e93-96.

9. NIH Consensus Conference (1989) Oral complications of cancer therapies: diagnosis, prevention, and treatment. National Institutes of Health Conn Med 53: 595-601.

10. Bedogni A, Fusco V, Agrillo A, Campisi G (2012) Learning from experience. Proposal of a refined definition and staging system for bisphosphonate-related osteonecrosis of the jaw (BRONJ). Oral Dis 18(6): 621-623.

11. Yarom N, Yahalom R, Shoshani Y, Hamed W, Regev E, et al (2017) Osteonecrosis of the jaw induced by orally administered bisphosphonates: incidence, clinical features, predisposing factors and treatment outcome. OsteoporosInt 18(10): 1363-1370.

12. Migliorati CA, Hujoel P (2007) Osteonecrosis of the jaw may not be a common acute side effect of oral bisphosphonates. J Evid Based Dent Pract 7(2): 77-78.

13. Woo SB, Hellstein JW, Kalmar JR (2006) Narrative [corrected] review: bisphosphonates and osteonecrosis of the jaws. Ann Intern Med 144: 753-761.

14. Marx RE, Sawatari Y, Fortin M, Broumand V (2005) Bisphosphonateinduced exposed bone (osteonecrosis/ osteopetrosis) of the jaws: risk factors, recognition, prevention, and treatment. J Oral Maxillofacial Surg 63: 1567-1575.

15. Yuh DY, Chang TH, Huang RY, Chien WC, Lin FG, et al. (2014) The national-scale cohort study on bisphosphonate-related osteonecrosis of the jaw in Taiwan. J Dent 42(10): 1343-1352.

\section{Your next submission with Juniper Publishers will reach you the below assets}

- Quality Editorial service

- Swift Peer Review

- Reprints availability

- E-prints Service

- Manuscript Podcast for convenient understanding

- Global attainment for your research

- Manuscript accessibility in different formats

( Pdf, E-pub, Full Text, Audio)

- Unceasing customer service

Track the below URL for one-step submission https://juniperpublishers.com/online-submission.php 